\title{
PENGARUH PARTISIPASI PENYUSUNAN ANGGARAN DAN \\ PERAN KUASA PENGGUNA ANGGARAN TERHADAP \\ KINERJA PEMERINTAH DAERAH KABUPATEN \\ KEPULAUAN TALAUD
}

\author{
Sinthia Anelia Kasili \\ David P. E. Saerang
}

\begin{abstract}
This research aims to discover the effects of Participation in Budget Preparation and the Role of Authority of the Budget User on the Regional Government Performance. The research was conducted in the Talaud Regency, one of the Autonomy Regions in North Sulawesi. The samples were taken using purposive sampling. The research sample was the Authorized Officials of Budget Users in Satuan Kerja Perangkat Daerah Pemerintah Kabupaten Kepulauan Talaud which were as many as 103 people.

The Multiple Linear Regression, descriptive statistics, classic assumption test, correlation coefficient $(R)$, determination coefficient $\left(R^{2}\right)$ and hypothesis testing ( $t$ test and $F$ test) were used to analyze the data. This method of analysis used the Software Statistical Products and Solution Services (SPSS) version 20.0.

The results of the research shows that the Participation in Budget Preparation and the Role of Authority of the Budget User on the Regional Government Performance both partially and simultaneously. Therefore, the hypotheses proposed in the research were accepted.
\end{abstract}

Keywords: Participation in Budget Preparation, Role of Authority of the Budget User, Regional Government Performance. 


\section{PENDAHULUAN}

Pelaksanaan otonomi daerah tidak hanya dapat dilihat dari seberapa besar daerah akan memperoleh sumber pendapatan termasuk dana perimbangan, tetapi hal tersebut harus diimbangi dengan sejauhmana instrumen atau Sistem Pengelolaan Keuangan Daerah mampu memberikan nuansa manajemen keuangan yang lebih adil, rasional, transparan, partisipatif dan bertanggungjawab (Darise, 2009:19).

Dalam konteks pengelolaan keuangan daerah implementasi program pemerintah daerah yang mengkonsumsi sejumlah sumber daya tertentu dapat dievaluasi melalui kinerja yang dihasilkan oleh setiap satuan kerja. Penggunaan anggaran merupakan konsep yang sering digunakan untuk melihat kinerja organisasi publik.

Anggaran yang telah ditetapkan untuk dilaksanakan oleh satuan kerja yang ada dalam pemerintah daerah dengan sendirinya akan berinteraksi dengan individu-individu yang ada dalam pemerintahan. Kinerja dari masing-masing individu tersebut akan berpengaruh pada kinerja pemerintahan secara menyeluruh. Dalam rangka mewujudkan kinerja pemerintahan secara menyeluruh tidak berhenti pada tahap penganggaran, namun dibutuhkan peran manajerial pimpinan daerah khususnya pengelola keuangan yang ada di daerah.

Partisipasi anggaran adalah salah satu cara untuk menciptakan sistem pengendalian manajemen yang baik sehingga diharapkan dapat tercapai tujuan institusi yang terkait. Partisipasi aparat pemerintah daerah dalam proses penganggaran pemerintah daerah mengarah pada seberapa besar tingkat keterlibatan aparat pemerintah daerah dalam menyusun anggaran daerah serta pelaksanaannya untuk mencapai target anggaran.

Berdasarkan uraian-uraian tersebut, penulis hendak melakukan penelitian replikasi yang mengambil objek Kabupaten Kepulauan Talaud dengan judul penelitian "Pengaruh Partisipasi Penyusunan Anggaran dan Peran Kuasa Pengguna Anggaran terhadap Kinerja Pemerintah Daerah Kabupaten Kepulauan Talaud”.

\section{LANDASAN TEORI}

\subsection{Partisipasi Penyusunan Anggaran}

Partisipasi bawahan dalam penyusunan anggaran mempunyai hubungan yang positif dengan pencapaian tujuan organisasi. Bawahan mempunyai kesempatan untuk melaporkan informasi yang dimiliki kepada atasannya, sehingga atasan dapat memilih keputusan yang baik untuk mencapai tujuan organisasi. Partisipasi merupakan cara efektif menyelaraskan tujuan pusat pertanggungjawaban dengan tujuan organisasi secara menyeluruh (Siegel dan Marconi, 1989 dalam Falikhatun,2007).

Menurut Brownell (1982) dalam Sardjito dan Muthaher (2007), partisipasi anggaran sebagai suatu proses dalam organisasi yang melibatkan para manajer dalam penentuan tujuan anggaran yang menjadi tanggung jawabnya. Partisipasi banyak menguntungkan bagi suatu organisasi, hal ini diperoleh dari hampir penelitian tentang partisipasi. Sord dan Welsch (1995) dalam Sardjito dan Muthaher (2007) mengemukakan bahwa tingkat partisipasi yang lebih tinggi akan menghasilkan moral yang lebih baik dan inisiatif yang lebih tinggi pula. Partisipasi telah ditunjukkan berpengaruh secara positif terhadap sikap pegawai, meningkatkan kuantitas dan kualitas produksi dan meningkatkan kerja sama diantara manajer.

Selanjutnya menurut Sardjito dan Muthaher (2007), partisipasi anggaran pada sektor publik terjadi ketika antara pihak eksekutif, legislatif dan masyarakat bekerja sama dalam pembuatan anggaran. Anggaran dibuat oleh kepala daerah melalui usulan dari unit-unit kerja yang disampaikan kepada kepala bagian dan diusulkan kepada kepala daerah dan setelah itu bersama-sama DPRD menetapkan anggaran yang dibuat sesuai dengan Peraturan Daerah yang berlaku.

\subsection{Peran Kuasa Pengguna Anggaran}


Peran menunjukkan partisipasi seseorang dalam mewujudkan tujuan organisasi. Peran manajerial pengelola keuangan daerah menunjukkan tercapainya mekanisme penyelenggaraan pemerintahan yang efisien dan efektif. Desentralisasi memberikan kesempatan Pengelola Keuangan Daerah untuk mendorong kreatifitas Pengelola Keuangan Daerah. Individu yang terlibat dan diberi tanggungjawab dalam penyusunan anggaran akan bekerja lebih keras untuk mencapai tujuan, sehingga kinerja organisasi akan semakin tinggi (Hansen dan Mowen, 2006 dalam Rohman, 2007).

Kuasa Pengguna Anggaran selain sebagai salah satu pihak yang bertanggungjawab dalam pengelolaan keuangan daerah juga bertanggungjawab atas pelaksanaan pemerintahan pada unit kerjanya masing-masing sesuai fungsinya sebagai sekretaris daerah, asisten, kepala bidang dan kepala kantor/satuan/unit kerja. Kuasa pengguna anggaran adalah pejabat yang memiliki kepentingan dalam menyusun, menggunakan dan melaporkan anggaran atau sebagai pelaksana keuangan dari Pemerintah Daerah.

\subsection{Kinerja Pemerintah Daerah}

Kinerja pemerintah daerah merupakan gambaran mengenai tingkat pencapaian pelaksanaan suatu kegiatan/program/kebijaksanaan dalam mewujudkan sasaran, tujuan, visi dan misi organisasi yang tertuang dalam perumusan skema strategis (strategic planning) suatu organisasi. Secara umum dapat juga dikatakan bahwa kinerja merupakan prestasi yang dapat dicapai organisasi dalam periode tertentu (Rohman, 2009).

Pengukuran kinerja pemerintah daerah diarahkan pada masing-masing satuan kerja yang telah diberi wewenang mengelola sumber daya sebagaimana bidangnya. Setiap satuan kerja adalah pusat pertanggungjawaban yang memiliki keunikan sendiri-sendiri. Dengan demikian perumusan indikator kinerja tidak bisa seragam untuk diterapkan pada semua satuan kerja yang ada. Namun demikian, dalam pengukuran kinerja setiap satuan kerja ini harus tetap dimulai dari pengidentifikasian visi, misi, falsafah, kebijakan, tujuan, sasaran, program, anggaran serta tugas dan fungsi yang telah ditetapkan (Mahsun 2009:198).

Pengukuran kinerja pemda berarti pengukuran kinerja terhadap satuan kerja atau entitas di lingkungan pemda. Fokus pengukuran kinerja untuk setiap satuan kerja atau entitas mencakup : (1) visi, misi, tujuan dan sasaran, (2) tugas pokok dan fungsi, (3) struktur organisasi dan personalia, (4) program kerja, (5) anggaran.

\subsection{HIPOTESIS}

Berdasarkan uraian-uraian dalam landasan teori, dapat dirumuskan hipotesis sebagai berikut:

H1 : Partisipasi Penyusunan Anggaran berpengaruh terhadap Kinerja Pemerintah Daerah Kabupaten Kepulauan Talaud.

H2 : Peran Kuasa Pengguna Anggaran berpengaruh terhadap Kinerja Pemerintah Daerah Kabupaten Kepulauan Talaud.

H3 : Partisipasi Penyusunan Anggaran dan Peran Kuasa Pengguna Anggaran berpengaruh terhadap Kinerja Pemerintah Daerah Kabupaten Kepulauan Talaud.

\section{METODE PENELITIAN}

\subsection{Populasi dan Sampel}

Data dalam penelitian ini diperoleh dari data primer melalui pembagian kuesioner dengan teknik sampling purposive sampling yakni teknik penentuan sampel dengan pertimbangan tertentu (Sugiyono, 2010:85). Sampel penelitian ini adalah pejabat Kuasa Pengguna Anggaran di lingkungan Pemerintah Kabupaten Kepulauan Talaud berjumlah 103 orang yang terdiri dari sekretaris daerah, asisten, kepala bidang, kepala kantor, kepala cabang dinas pendidikan, kepala sekolah, kepala puskesmas, kepala UPTD dan lurah. 


\subsection{Metode Analisis Data}

Analisis data menggunakan Software Statistical Products and Solution Services (SPSS) dengan lima tahap. Tahap pertama, statistik deskriptif. Tahap kedua, pengujian kualitas data. Tahap ketiga, melakukan uji penyimpangan asumsi klasik. Tahap keempat, melakukan analisis regresi linear berganda dan tahap kelima melakukan pengujian hipotesis.

\section{ANALISIS DAN EVALUASI}

\subsection{Gambaran Umum Responden}

Berdasarkan kuesioner disebar dan yang dapat dikembalikan maka diperoleh rincian distribusi kuesioner sebagai berikut:

Rincian Distribusi Kuesioner

\begin{tabular}{|l|c|c|}
\hline \multicolumn{1}{|c|}{ Keterangan } & Total & Persentase \\
\hline Kuesioner yang didistribusikan & 100 & $100 \%$ \\
\hline Kuesioner yang tidak kembali & $(5)$ & $5 \%$ \\
\hline Kuesioner yang kembali & 95 & $95 \%$ \\
\hline Kuesioner yang rusak & $(6)$ & $6 \%$ \\
\hline Kuesioner yang dapat diolah & 89 & $89 \%$ \\
\hline
\end{tabular}

Sumber: Data primer yang diolah, 2012

\subsection{Statistik Deskriptif}

Statistik deskriptif berhubungan dengan penggambaran atau peringkasan data penelitian sehingga data tersebut mudah dipahami. Data hasil tabulasi yang diolah dengan menggunakan Software SPSS 20.0 menghasilkan deskripsi statistik variabel penelitian seperti pada tabel berikut:

\section{Statistik Deskriptif}

\begin{tabular}{|l|c|c|c|}
\hline & Mean & Std. Deviation & $\mathrm{N}$ \\
\hline Kinerja Pemerintah Daerah (Y) & 27.1685 & 5.11734 & 89 \\
\hline Partisipasi Penyusunan Anggaran (X1) & 25.1011 & 4.63447 & 89 \\
\hline Peran Kuasa Pengguna Anggaran (X2) & 26.8315 & 4.68614 & 89 \\
\hline
\end{tabular}

Sumber : Output Software SPSS 20.0

Tabel statistik deskriptif menginformasikan hal-hal berikut:

Untuk variabel $\mathrm{X}_{1}$ (Partisipasi Penyusunan Anggaran) diperoleh rata-rata hitung skor jawaban responden 25.1011 dengan standar deviasi sebesar 4.63447 dan jumlah responden sebanyak 89. Standar deviasi yang lebih kecil dari rata-rata menunjukkan data terkelompok dengan baik.

Untuk variabel $\mathrm{X}_{2}$ (Peran Kuasa Pengguna Anggaran) diperoleh rata-rata hitung skor jawaban responden 26.8315 dengan standar deviasi sebesar 4.68614 dan jumlah responden sebanyak 89. Standar deviasi yang lebih kecil dari rata-rata menunjukkan data terkelompok dengan baik.

Untuk variabel Y (Kinerja Pemerintah Daerah) diperoleh rata-rata hitung skor jawaban responden 27.1685 dengan standar deviasi sebesar 5.11734 dan jumlah responden sebanyak 89. Standar deviasi yang lebih kecil dari rata-rata menunjukkan data terkelompok dengan baik.

\subsection{Uji Kualitas Data}

Data utama yang digunakan dalam penelitian ini adalah data primer dengan kuesioner sebagai alat utama untuk memperoleh data. Untuk meyakinkan akan kualitas data yang akan diolah, terlebih dahulu diuji validitas dan reliabilitasnya. 
Hasil Uji Validitas Variabel Partisipasi Penyusunan Anggaran $\left(\mathbf{X}_{1}\right)$

\begin{tabular}{|l|c|c|c|c|}
\hline Indikator & $\begin{array}{c}\text { Pearson } \\
\text { Correlation }\end{array}$ & Signifikansi & Keterangan & $\begin{array}{c}\text { Tingkat } \\
\text { Hubungan }\end{array}$ \\
\hline Pertanyaan 1 & 0,543 & 0,000 & Valid & Cukup Kuat \\
Pertanyaan 2 & 0,544 & 0,000 & Valid & Cukup Kuat \\
Pertanyaan 3 & 0,550 & 0,000 & Valid & Cukup Kuat \\
Pertanyaan 4 & 0,664 & 0,000 & Valid & Kuat \\
Pertanyaan 5 & 0,803 & 0,000 & Valid & Sangat Kuat \\
Pertanyaan 6 & 0,639 & 0,000 & Valid & Kuat \\
Pertanyaan 7 & 0,104 & 0,529 & Tidak Valid & Sangat Rendah \\
Pertanyaan 8 & 0,358 & 0,025 & Valid & Rendah \\
Pertanyaan 9 & 0,321 & 0,046 & Valid & Rendah \\
Pertanyaan 10 & 0,434 & 0,006 & Valid & Cukup Kuat \\
\hline
\end{tabular}

Sumber : Data Olahan dari Output SPSS

Tabel Hasil Uji Validitas Variabel Partisipasi Penyusunan Anggaran $\left(\mathrm{X}_{1}\right)$ menunjukkan bahwa hasil uji validitas untuk variabel partisipasi penyusunan anggaran dengan 10 butir pertanyaan ternyata 1 pertanyaan yakni pertanyaan 7 dinyatakan tidak valid karena nilai signifikansinya 0,529 lebih besar dari $\alpha=0,05$ dan nilai koefisien korelasinya 0,104 lebih kecil dari 0,30 .

Hasil Uji Validitas Variabel Peran Kuasa Pengguna Anggaran $\left(X_{2}\right)$

\begin{tabular}{|c|c|c|c|c|}
\hline Indikator & $\begin{array}{c}\text { Pearson } \\
\text { Correlation }\end{array}$ & Signifikansi & Keterangan & $\begin{array}{c}\text { Tingkat } \\
\text { Hubungan }\end{array}$ \\
\hline Pertanyaan 1 & 0,748 & 0,000 & Valid & Kuat \\
Pertanyaan 2 & 0,547 & 0,000 & Valid & Cukup Kuat \\
Pertanyaan 3 & 0,606 & 0,000 & Valid & Kuat \\
Pertanyaan 4 & 0,671 & 0,000 & Valid & Kuat \\
Pertanyaan 5 & $-0,115$ & 0,487 & Tidak Valid & - \\
Pertanyaan 6 & 0,470 & 0,003 & Valid & Cukup Kuat \\
Pertanyaan 7 & 0,781 & 0,000 & Valid & Kuat \\
Pertanyaan 8 & 0,634 & 0,000 & Valid & Kuat \\
Pertanyaan 9 & 0,498 & 0,001 & Valid & Cukup Kuat \\
Pertanyaan 10 & 0,622 & 0,000 & Valid & Kuat \\
\hline
\end{tabular}

Sumber : Data Olahan dari Output SPSS

Tabel Hasil Uji Validitas Variabel Peran Kuasa Pengguna Anggaran $\left(\mathrm{X}_{2}\right)$ menunjukkan bahwa hasil uji validitas untuk variabel peran manajer pengelola keuangan daerah dengan 10 butir pertanyaan ternyata 1 pertanyaan yakni pertanyaan 5 dinyatakan tidak valid karena nilai signifikansinya -0,115 meskipun koefisien korelasinya 0,487 .

Hasil Uji Validitas Variabel Kinerja Pemerintah Daerah (Y)

\begin{tabular}{|c|c|c|c|c|}
\hline Indikator & $\begin{array}{c}\text { Pearson } \\
\text { Correlation }\end{array}$ & Signifikansi & Keterangan & $\begin{array}{c}\text { Tingkat } \\
\text { Hubungan }\end{array}$ \\
\hline Pertanyaan 1 & 0,713 & 0,000 & Valid & Kuat \\
Pertanyaan 2 & 0,682 & 0,000 & Valid & Kuat \\
Pertanyaan 3 & 0,503 & 0,001 & Valid & Cukup Kuat \\
Pertanyaan 4 & 0,616 & 0,000 & Valid & Kuat \\
Pertanyaan 5 & 0,648 & 0,000 & Valid & Kuat \\
Pertanyaan 6 & 0,577 & 0,000 & Valid & Cukup Kuat \\
Pertanyaan 7 & 0,633 & 0,000 & Valid & Kuat \\
Pertanyaan 8 & 0,917 & 0,000 & Valid & Sangat Kuat \\
\hline
\end{tabular}




\begin{tabular}{|c|c|c|c|c|}
\hline Pertanyaan 9 & 0,857 & 0,000 & Valid & Sangat Kuat \\
Pertanyaan 10 & 0,637 & 0,000 & Valid & Kuat \\
\hline
\end{tabular}

Sumber : Data Olahan dari Output SPSS

Tabel Hasil Uji Validitas Variabel Kinerja Pemerintah Daerah (Y) menunjukkan bahwa hasil uji validitas untuk variabel kinerja pemerintah daerah dengan 10 butir pertanyaan semua dinyatakan valid karena memiliki nilai signifikansi dibawah $\alpha=0,05$ dan koefisien korelasi diatas 0,30 .

Hasil Uji Reliabilitas

\begin{tabular}{|l|c|c|c|c|}
\hline \multicolumn{1}{|c|}{ Variabel } & $\begin{array}{c}\text { Cronbach } \\
\text { Alpha }\end{array}$ & Standar & Keterangan & Kriteria \\
\hline $\begin{array}{l}\text { Partisipasi Penyusunan } \\
\text { Anggaran }\left(\mathrm{X}_{1}\right)\end{array}$ & 0,672 & 0,6 & Reliabel & Tinggi \\
\hline $\begin{array}{l}\text { Peran Kuasa Pengguna } \\
\text { Anggaran }\left(\mathrm{X}_{2}\right)\end{array}$ & 0,701 & 0,6 & Reliabel & Tinggi \\
\hline $\begin{array}{l}\text { Kinerja Pemerintah Daerah } \\
(\mathrm{Y})\end{array}$ & 0,863 & 0,6 & Reliabel & $\begin{array}{c}\text { Sangat } \\
\text { Tinggi }\end{array}$ \\
\hline
\end{tabular}

Sumber : Data Olahan dari Output SPSS

Tabel Hasil Uji Reliabilitas menunjukkan bahwa ketiga variabel dinyatakan reliabel dengan penjelasan sebagai berikut:

Uji reliabilitas untuk variabel Partisipasi Penyusunan Anggaran $\left(\mathrm{X}_{1}\right)$ menunjukkan nilai Cronbach Alpha atau $r$ hitung $=0,672$ lebih besar dari $r$ tabel $=0,316$ dan juga lebih besar dari nilai yang distandarkan yakni 0,6 .

Uji reliabilitas untuk variabel Peran Kuasa Pengguna Anggaran $\left(\mathrm{X}_{2}\right)$ menunjukkan nilai Cronbach Alpha atau $r$ hitung $=0,701$ lebih besar dari $r$ tabel $=0,316$ dan juga lebih besar dari nilai yang distandarkan yakni 0,6 .

Uji reliabilitas untuk variabel Kinerja Pemerintah Daerah (Y) menunjukkan nilai Cronbach Alpha atau $r$ hitung $=0,863$ lebih besar dari $r$ tabel $=0,316$ dan juga lebih besar dari nilai yang distandarkan yakni 0,6.

\subsection{Uji Asumsi Klasik}

\section{Uji Normalitas}

Pengujian normalitas adalah pengujian tentang kenormalan distribusi data. Penggunaan uji normalitas karena pada analisis statistik parametrik, asumsi yang harus dimiliki oleh data adalah bahwa data tersebut harus terdistribusi secara normal.

\section{Hasil Uji Normalitas menggunakan}

Histogram Regression Standardized Residual

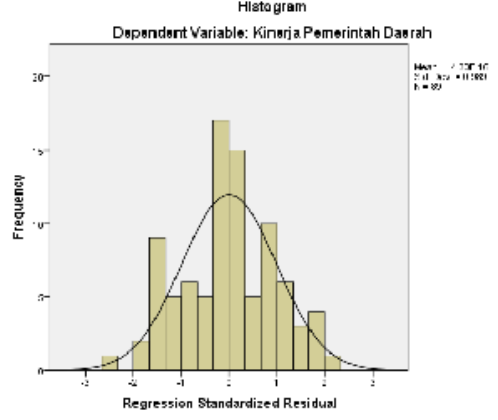

Sumber : Output Software SPSS 20.0

Gambar diatas menunjukkan bahwa data membentuk kurva yang jika digambarkan berbentuk lonceng (bell shaped curve). Dengan demikian dapat disimpulkan bahwa data terdistribusi secara normal. 


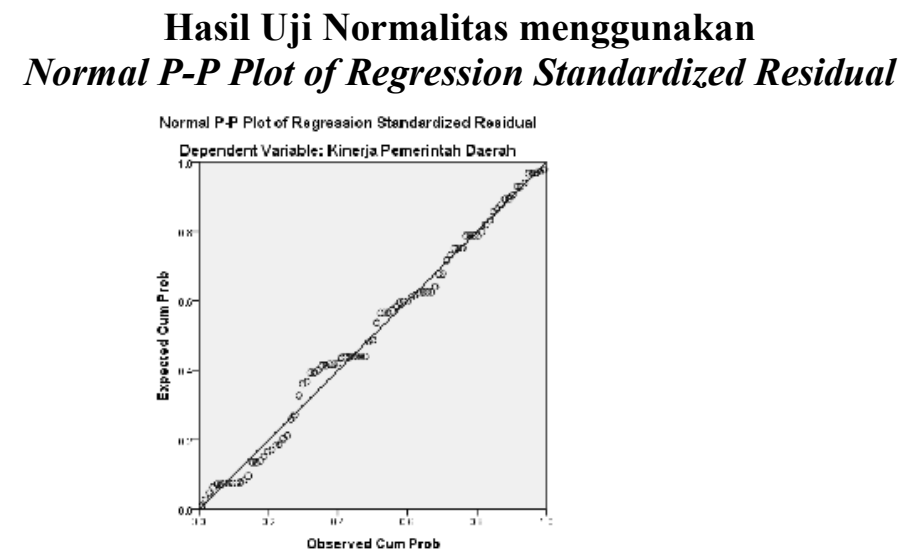

Sumber : Output Software SPSS 20.0

Gambar diatas menunjukkan bahwa titik-titik yang berarti data menyebar disekitar garis diagonal dan mengikuti arah garis diagonal yang merupakan perpotongan antara garis probabilitas harapan dan probabilitas pengamatan. Dengan demikian dapat disimpulkan bahwa data terdistribusi secara normal.

\section{Uji Multikolinearitas}

Asumsi multikolinearitas menyatakan bahwa variabel independen harus terbebas dari gejala multikolinearitas.

\begin{tabular}{|l|c|c|}
\multicolumn{3}{|c|}{ Hasil Uji Multikolinearitas } \\
\hline \multirow{2}{*}{ Model } & Collinearity Statistics \\
\cline { 2 - 3 } & Tolerance & VIF \\
\hline Partisipasi Penyusunan Anggaran (X1) & 0,430 & 2,324 \\
\hline Peran Kuasa Pengguna Anggaran (X2) & 0,430 & 2,324 \\
\hline
\end{tabular}

Sumber : Output Software SPSS 20.0

Tabel Hasil Uji Multikolinearitas menunjukkan bahwa semua variabel independen memiliki nilai Variance Inflation Factor (VIF) kurang dari 10 yaitu 2,324 dan nilai Tolerance lebih dari 0.1 yaitu 0,430 sehingga dapat disimpulkan bahwa variabel independen terbebas dari gejala multikolinearitas.

\section{Uji Heteroskedastisitas}

Dalam regresi, salah satu asumsi yang harus dipenuhi adalah bahwa varians dari residual dari satu pengamatan ke pengamatan yang lain tetap atau homokedastisitas.

\section{Hasil Uji Heteroskedastisitas}

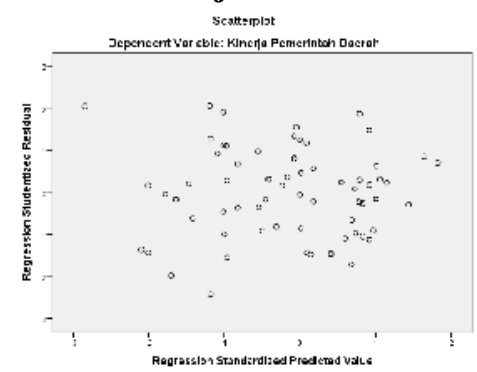

Sumber : Output Software SPSS 20.0

Gambar diatas menunjukkan bahwa titik-titik yang berarti data dalam posisi menyebar dan tidak membentuk pola tertentu sehingga dapat disimpulkan bahwa model regresi terbebas dari heteroskedastisitas.

Uji Autokorelasi 
Uji autokorelasi merupakan pengujian asumsi dalam regresi dimana variabel dependen tidak berkorelasi dengan dirinya sendiri. Maksud korelasi dengan diri sendiri adalah bahwa nilai dari variabel dependen tidak berhubungan dengan nilai variabel itu sendiri pada suatu pengamatan dengan pengamatan yang lain

Hasil Uji Autokorelasi

\begin{tabular}{|c|c|c|c|c|}
\hline $\mathrm{R}$ & $\mathrm{R}$ Square & $\begin{array}{c}\text { Adjusted R } \\
\text { Square }\end{array}$ & $\begin{array}{c}\text { Std. Error of the } \\
\text { Estimate }\end{array}$ & $\begin{array}{c}\text { Durbin- } \\
\text { Watson }\end{array}$ \\
\hline 0,664 & 0,441 & 0,428 & 3,87054 & 1,918 \\
\hline
\end{tabular}

Sumber : Output Software SPSS 20.0

Tabel Hasil Uji Autokorelasi menunjukkan bahwa nilai DW $=1,918$. Berdasarkan tabel $\mathrm{d}$ (Durbin-Watson), nilai $\mathrm{dL}=1,382$ dan nilai $\mathrm{dU}=1,597$. Karena nilai $\mathrm{DW}=1,918$ berada pada kisaran dU sampai dengan $4-\mathrm{dU}$ yaitu 1,597 sampai dengan 2,403 maka dapat disimpulkan bahwa tidak terjadi autokorelasi.

\section{Analisis Regresi Linear Berganda}

Analisis Regresi Linear Berganda merupakan suatu analisis asosiasi yang digunakan secara bersamaan untuk meneliti pengaruh dua atau lebih variabel bebas (independent) terhadap satu variabel terikat (dependent) dengan skala interval (Wijaya, 2010:6).

Persamaan analisis regresi linear berganda yang digunakan dalam penelitian ini adalah sebagai berikut: $\quad \mathbf{Y}=\boldsymbol{\alpha}+\boldsymbol{\beta} \mathbf{I X} \mathbf{I}+\boldsymbol{\beta} 2 \mathbf{X} \mathbf{2}+\boldsymbol{\varepsilon}$

\section{Dimana :}

$\mathrm{Y}=$ Kinerja Pemerintah Daerah

$\alpha=$ Konstanta

$\beta 1=$ Koefisien regresi untuk $X_{1}$

$\beta 2=$ Koefisien regresi untuk X2

$\varepsilon=$ Error term

$\mathrm{X}_{1}=$ Partisipasi Penyusunan Anggaran

X2 = Peran Kuasa Pengguna Anggaran

Hasil Analisis Regresi Linear Berganda

\begin{tabular}{|c|c|c|c|c|c|c|c|}
\hline \multirow{2}{*}{ Model } & \multicolumn{2}{|c|}{$\begin{array}{c}\text { Unstandardized } \\
\text { Coefficients }\end{array}$} & \multirow{2}{*}{$\begin{array}{c}\begin{array}{c}\text { Standardized } \\
\text { Coefficients }\end{array} \\
\text { Beta }\end{array}$} & \multirow{2}{*}{$\mathrm{t}$} & \multirow{2}{*}{ Sig. } & \multicolumn{2}{|c|}{$\begin{array}{c}\text { Collinearity } \\
\text { Statistics }\end{array}$} \\
\hline & B & $\begin{array}{l}\text { Std. } \\
\text { Error }\end{array}$ & & & & Tolerance & VIF \\
\hline (Constant) & 7,142 & 2,495 & & 2,863 & 0,005 & & \\
\hline $\begin{array}{l}\text { Partisipasi } \\
\text { Penyusunan } \\
\text { Anggaran (X1) }\end{array}$ & 0,473 & 0,136 & 0,429 & 3,486 & 0,001 & 0,430 & 2,324 \\
\hline $\begin{array}{l}\text { Peran Kuasa } \\
\text { Pengguna } \\
\text { Anggaran (X2) }\end{array}$ & 0,304 & 0,134 & 0,278 & 2,263 & 0,026 & 0,430 & 2,324 \\
\hline
\end{tabular}

Sumber : Output Software SPSS 20.0

Berdasarkan tabel Hasil Analisis Regresi Linear Berganda dapat dilihat persamaan regresi linear berganda adalah :

$$
\begin{gathered}
\mathrm{Y}=\alpha+\beta 1 \mathrm{X}_{1}+\beta 2 \mathrm{X} 2 \\
\text { Kinerja PEMDA }=7,142+0,473 \mathrm{PPA}+0,304 \mathrm{PKPA}
\end{gathered}
$$

Persamaan tersebut dapat dijelaskan sebagai berikut :

Konstanta $\alpha$ sebesar 7,142 mempunyai arti bahwa jika Partisipasi Penyusunan Anggaran dan Peran Kuasa Pengguna Anggaran konstan atau sama dengan nol (0), maka besarnya variabel Kinerja Pemerintah Daerah (Y) sebesar 7,142. 
Nilai $\beta_{1}$ yang merupakan koefisien regresi dari variabel $X_{1}$ (Partisipasi Penyusunan Anggaran) sebesar 0,473 mempunyai arti bahwa jika variabel Partisipasi Penyusunan Anggaran mengalami peningkatan 1\%, maka besarnya variabel Kinerja Pemerintah Daerah (Y) juga akan ikut mengalami kenaikan atau peningkatan sebesar 0,473 dengan asumsi variabel $\mathrm{X}_{2}$ (Peran Kuasa Pengguna Anggaran) tetap atau konstan.

Nilai $\beta_{2}$ yang merupakan koefisien regresi dari variabel $X_{2}$ (Peran Kuasa Pengguna Anggaran) sebesar 0,304 mempunyai arti bahwa jika variabel Peran Kuasa Pengguna Anggaran mengalami peningkatan sebesar 1\%, maka besarnya variabel Kinerja Pemerintah Daerah (Y) juga akan ikut mengalami kenaikan atau peningkatan sebesar 0,304 dengan asumsi variabel $\mathrm{X}_{1}$ (Partisipasi Penyusunan Anggaran) tetap atau konstan.

Dengan demikian dapat diketahui bahwa terdapat hubungan yang kuat dan searah antara variabel bebas $\mathrm{X}_{1}$ dan $\mathrm{X}_{2}$ dengan variabel terikat $\mathrm{Y}$, dimana angka koefisien regresi yang diperoleh semuanya menunjukkan tanda positif $(+)$.

Koefisien Korelasi (R)

Koefisien korelasi (R) digunakan untuk mengukur keeratan hubungan antara dua atau lebih variabel independen (X1, dan X2) terhadap variabel dependen (Y) secara serentak.

\section{Koefisien Korelasi}

\begin{tabular}{|c|c|c|c|c|}
\hline $\mathrm{R}$ & R Square & $\begin{array}{c}\text { Adjusted R } \\
\text { Square }\end{array}$ & $\begin{array}{c}\text { Std. Error of the } \\
\text { Estimate }\end{array}$ & $\begin{array}{c}\text { Durbin- } \\
\text { Watson }\end{array}$ \\
\hline 0,664 & 0,441 & 0,428 & 3,87054 & 1,918 \\
\hline
\end{tabular}

Sumber : Output Software SPSS 20.0

Tabel Koefisien Korelasi menunjukkan bahwa nilai koefisien korelasi (R) adalah sebesar 0,664 yang memberi arti bahwa terdapat hubungan yang kuat dan searah antara Partisipasi Penyusunan Anggaran dan Peran Kuasa Pengguna Anggaran terhadap Kinerja Pemerintah Daerah.

\section{Koefisien Determinasi $\left(\mathbf{R}^{2}\right)$}

Koefisien determinasi $\left(\mathrm{R}^{2}\right)$ adalah nilai yang digunakan untuk melihat sejauh mana model yang terbentuk dapat menjelaskan kondisi yang sebenarnya.

\section{Koefisien Determinasi}

\begin{tabular}{|c|c|c|c|c|}
\hline $\mathrm{R}$ & R Square & $\begin{array}{c}\text { Adjusted R } \\
\text { Square }\end{array}$ & $\begin{array}{c}\text { Std. Error of the } \\
\text { Estimate }\end{array}$ & $\begin{array}{c}\text { Durbin- } \\
\text { Watson }\end{array}$ \\
\hline 0,664 & 0,441 & 0,428 & 3,87054 & 1,918 \\
\hline
\end{tabular}

Sumber : Output Software SPSS 20.0

Tabel Koefisien Determinasi menunjukkan bahwa nilai koefisien determinasi $\left(\mathrm{R}^{2}\right)$ adalah sebesar 0,441 atau 44,1\% sehingga dapat disimpulkan bahwa Kinerja Pemerintah Daerah (Y) mendapat kontribusi dari Partisipasi Penyusunan Anggaran $\left(\mathrm{X}_{1}\right)$ dan Peran Kuasa Pengguna Anggaran $\left(\mathrm{X}_{2}\right)$ sebesar 44,1\% sedangkan sisanya 55,9\% mendapat kontribusi dari faktor atau variabel lain yang tidak diteliti dalam penelitian ini.

\subsection{Pengujian Hipotesis}

Uji Statistik t pada dasarnya menunjukkan seberapa jauh pengaruh satu variabel independen secara individual dalam menerangkan variasi variabel dependen.

\section{Hasil Uji t}

\begin{tabular}{|l|c|c|c|c|c|c|c|}
\hline \multirow{3}{*}{ Model } & \multicolumn{2}{|c|}{$\begin{array}{c}\text { Unstandardized } \\
\text { Coefficients }\end{array}$} & $\begin{array}{c}\text { Standardized } \\
\text { Coefficients }\end{array}$ & \multirow{2}{*}{$\mathrm{t}$} & Sig. & \multicolumn{2}{|c|}{$\begin{array}{c}\text { Collinearity } \\
\text { Statistics }\end{array}$} \\
\cline { 2 - 4 } \cline { 7 - 9 } & $\mathrm{B}$ & $\begin{array}{c}\text { Std. } \\
\text { Error }\end{array}$ & Beta & & & Tolerance & VIF \\
\hline (Constant) & 7,142 & 2,495 & & 2,863 & 0,005 & & \\
\hline
\end{tabular}




\begin{tabular}{||l|c|c|c|c|c|c|c|}
\hline $\begin{array}{l}\text { Partisipasi } \\
\text { Penyusunan } \\
\text { Anggaran (X1) }\end{array}$ & 0,473 & 0,136 & 0,429 & 3,486 & 0,001 & 0,430 & 2,324 \\
\hline $\begin{array}{l}\text { Peran Kuasa } \\
\text { Pengguna } \\
\text { Anggaran (X2) }\end{array}$ & 0,304 & 0,134 & 0,278 & 2,263 & 0,026 & 0,430 & 2,324 \\
\hline
\end{tabular}

Sumber : Output Software SPSS 20.0

Berdasarkan Tabel Hasil Uji t, dapat dilakukan pengujian hipotesis sebagai berikut:

Pengujian $\mathrm{H}_{1}$ Partisipasi Penyusunan Anggaran berpengaruh terhadap Kinerja Pemerintah Daerah

Hasil uji t variabel Partisipasi Penyusunan Anggaran (X1), thitung $=3,486$ dan ttabel $=$ 1,671 dan nilai signifikansi $0,001<0,05$. Karena thitung $>$ ttabel dan nilai sig. $<0,05$ berarti Partisipasi Penyusunan Anggaran secara parsial berpengaruh terhadap Kinerja Pemerintah Daerah. Dengan demikian dapat disimpulkan bahwa H1 diterima.

Pengujian $\mathrm{H}_{2}$ Peran Kuasa Pengguna Anggaran berpengaruh terhadap Kinerja Pemerintah Daerah

Hasil uji t variabel Peran Kuasa Pengguna Anggaran (X2), thitung = 2,263 dan ttabel $=$ 1,671 dan nilai signifikansi $0,026<0,05$. Karena thitung $>$ ttabel dan nilai sig. $<0,05$ berarti Peran Kuasa Pengguna Anggaran secara parsial berpengaruh terhadap Kinerja Pemerintah Daerah. Dengan demikian dapat disimpulkan bahwa $\mathrm{H} 2$ diterima.

Secara simultan, pengujian hipotesis dilakukan dengan uji F-test (ANOVA test). Uji Statistik $\mathrm{F}$ pada dasarnya menunjukkan apakah semua variabel independen atau bebas yang dimasukkan dalam model mempunyai pengaruh secara bersama-sama terhadap variabel dependen.

Hasil Uji F

\begin{tabular}{|l|c|c|c|c|c|}
\hline \multicolumn{1}{|c|}{ Model } & Sum of Squares & df & Mean Square & F & Sig. \\
\hline Regression & 1016,098 & 2 & 508,049 & 33,913 & 0,000 \\
\hline Residual & 1288,374 & 86 & 14,981 & & \\
\hline Total & 2304,472 & 88 & & & \\
\hline
\end{tabular}

Sumber : Output Software SPSS 20.0

Berdasarkan Tabel Hasil Uji F, dapat dilakukan pengujian hipotesis sebagai berikut:

Pengujian $\mathrm{H}_{3}$ Partisipasi Penyusunan Anggaran dan Peran Kuasa Pengguna Anggaran berpengaruh terhadap Kinerja Pemerintah Daerah

Uji ANOVA menunjukkan bahwa Fhitung $=33,913$ dan Ftabel $=3,32$ dan nilai signifikansi $=0,000$. Karena Fhitung $>$ Ftabel dan nilai sig. $<0,05$ berarti Partisipasi Penyusunan Anggaran dan Peran Kuasa Pengguna Anggaran secara simultan berpengaruh signifikan terhadap variabel Kinerja Pemerintah Daerah.

\section{KESIMPULAN DAN SARAN}

\subsection{Kesimpulan}

Berdasarkan hasil analisis data dan pengujian hipotesis yang telah diuraikan pada bab sebelumnya, maka diperoleh kesimpulan mengenai pengaruh Partisipasi Penyusunan Anggaran dan Peran Kuasa Pengguna Anggaran terhadap Kinerja Pemerintah Daerah sebagai berikut :

1. Partisipasi Penyusunan Anggaran berpengaruh terhadap Kinerja Pemerintah Daerah. Hal ini menunjukan bahwa semakin tinggi Partisipasi Penyusunan Anggaran maka semakin meningkat Kinerja Pemerintah Daerah. 
2. Peran Kuasa Pengguna Anggaran berpengaruh terhadap Kinerja Pemerintah Daerah. Hal ini menunjukan bahwa semakin tinggi Peran Kuasa Pengguna Anggaran maka akan semakin meningkatkan Kinerja Pemerintah Daerah.

3. Partisipasi Penyusunan Anggaran dan Peran Kuasa Pengguna Anggaran secara bersama-sama berpengaruh signifikan terhadap Kinerja Pemerintah Daerah.

\subsection{Saran}

Berdasarkan kesimpulan, maka penulis memberikan saran untuk penelitian selanjutnya, yaitu:

3. Pemerintah Kabupaten Kepulauan Talaud sebaiknya mengoptimalkan penerapan anggaran partisipatif karena hal ini akan berdampak pada meningkatnya kinerja pemerintah daerah.

4. Pemerintah Kabupaten Kepulauan Talaud sebaiknya menempatkan pegawai sesuai keahlian yang dimiliki agar pegawai dapat mengoptimalkan kinerjanya sehingga berdampak pada meningkatnya kinerja pemerintah daerah.

5. Untuk penelitian selanjutnya di instansi pemerintah sebaiknya memperhatikan hal-hal berikut:

1) Menggunakan variabel independen maupun dependen lain seperti motivasi, senjangan anggaran, kenaikan gaji, jam kerja, gaya kepemimpinan, kepuasan kerja, dan lainnya serta menambah variabel moderating, intervening yang memiliki kemungkinan untuk berpengaruh terhadap hubungan antara partisipasi penyusunan anggaran dan peran pengelola keuangan daerah terhadap kinerja pemerintah daerah.

2) Menambah jumlah sampel yang diteliti agar hasilnya lebih representatif terhadap populasi yang dipilih sehingga analisis akan lebih akurat.

3) Memperhatikan penggunaan materi kuesioner agar lebih disesuaikan dengan kondisi pemerintahan.

\section{DAFTAR PUSTAKA}

Antara News. 2007. Ketua BPK : Kinerja Pemda Masih Jauh dari Memuaskan. Ambon : 30 April 2007.

Antara News. 2007. Untuk Raih Gelar Doktor di UGM, Fadel Muhammad Sampaikan Teori Kepemimpinan. Gorontalo : 10 Agustus 2007.

Darise, Nurlan. 2008. Akuntansi Keuangan Daerah (Akuntansi Sektor Publik). Jakarta : PT Indeks

Darise, Nurlan. 2009. Pengelolaan Keuangan Daerah. Jakarta : PT Indeks

Falikhatun. 2007. Interaksi Informasi Asimetri, Budaya Organisasi dan Group Cohesiveness dalam Hubungan antara Partisipasi Penganggaran dan Budgetary Slack (Studi Kasus pada Rumah Sakit Umum Daerah se-Jawa Tengah). Simposium Nasional Akuntansi X, Unhas Makassar 26-28 Juli 2007.

Herminingsih. 2009. Pengaruh Partisipasi dalam Penganggaran dan Peran Manajerial Pengelola Keuangan Daerah terhadap Kinerja Pemerintah Daerah. Tesis S2 Program Pasca Sarjana Magister Akuntansi, Universitas Diponegoro Semarang.

Indriantoro, Nur dan Bambang Supomo. 2009. Metodologi Penelitian Bisnis untuk Akuntansi dan Manajemen. Yogyakarta : BPFE.

Kuncoro, Mudrajad. 2009. Metode Riset untuk Bisnis dan Ekonomi. Jakarta : Erlangga.

Mahsun, Mohamad. 2009. Pengukuran Kinerja Sektor Publik. Yogyakarta : BPFE.

Mardiasmo. 2009. Akuntansi Sektor Publik. Yogyakarta : Penerbit Andi.

Nurcahyani, Kunwaviyah. 2010. Pengaruh Partisipasi Anggaran terhadap Kinerja Manajerial melalui Komitmen Organisasi dan Persepsi Inovasi sebagai Variabel Intervening. Skripsi S1 Fakultas Ekonomi, Universitas Diponegoro Semarang. 
Ompusunggu, Krisler Bornardi dan Icuk Rangga Bawono. 2007. Pengaruh Partisipasi Anggaran dan Job Relevant Information (JRI) terhadap Informasi Asimetris (Studi pada Badan Layanan Umum Universitas Negeri di Kota Purwokerto Jawa Tengah). Jurnal Akuntansi dan Keuangan Sektor Publik, Vol. 08 No. 01, Februari 2007.

Putri, Natalia Dewinda. 2010. Pengaruh Komitmen Organisasional dan Peran Manajer Pengelolaan Keuangan Daerah terhadap Kinerja Manajerial Satuan Kerja Perangkat Daerah (Studi pada Kabupaten Tegal). Skripsi S1 Fakultas Ekonomi, Universitas Diponegoro Semarang.

Rohman, Abdul. 2007. Pengaruh Peran Manajerial Pengelola Keuangan Daerah dan Fungsi Pemeriksaan Intern terhadap Kinerja Pemerintah Daerah (Survei pada Pemda Kota, Kabupaten dan Provinsi di Jawa Tengah). Jurnal Maksi, Vol. 7 No. 02, Agustus 2007 : 206-220.

Rohman, Abdul. 2009. Pengaruh Implementasi Sistem Akuntansi, Pengelolaan Keuangan Daerah terhadap Fungsi Pengawasan dan Kinerja Pemerintah Daerah (Survei pada Pemda di Jawa Tengah). Jurnal Akuntansi \& Bisnis, Vol. 9 No. 1, Februari 2009 : 2132.

Sabeni, Arifin dan Imam Ghozali. 2008. Pokok-pokok Akuntansi Pemerintahan. Yogyakarta : BPFE.

Santosa, Purbayu Budi dan Ashari. 2005. Analisis Statistik dengan Microsoft Excel dan SPSS. Yogyakarta : Penerbit Andi.

Sardjito, Bambang dan Osmad Muthaher. 2007. Pengaruh Partisipasi Penyusunan Anggaran terhadap Kinerja Aparat Pemerintah Daerah : Budaya Organisasi dan Komitmen Organisasi sebagai Variabel Moderating. Simposium Nasional Akuntansi X, Unhas Makassar 26-28 Juli 2007.

Sugiyono. 2010. Metode Penelitian Kuantitatif Kualitatif dan R\&D. Bandung : Alfabeta.

Suharyadi dan Purwanto. 2007.Statistika Bisnis. Jakarta : Salemba Empat.

Tim Redaksi Fokusmedia. 2008. Peraturan Menteri Dalam Negeri Nomor 13 Tahun 2006 dan Perubahannya Nomor 59 Tahun 2007 tentang Pedoman Pengelolaan Keuangan Daerah. Bandung : Fokusmedia.

Wibowo, Agung Edy. 2012. Aplikasi Praktis SPSS Dalam Penelitian. Yogyakarta : Gava Media.

Wijaya, Toni. 2010. Analisis Statistik Multivariat. Bandung : Alfabeta. 